\title{
MALIGNANT POROMA SYNONYM: POROCARCINOMA ECCRINE POROMA MALIGNANT
}

Divvya B1, M. Valluvan², Rehana Tippoo³, P. Viswanathan4, R. Ramesh ${ }^{5}$

\section{HOW TO CITE THIS ARTICLE:}

Divvya B, M. Valluvan, Rehana Tippoo, P. Viswanathan, R. Ramesh. “Malignant Poroma Synonym:

Porocarcinoma Eccrine Poroma Malignant". Journal of Evolution of Medical and Dental Sciences 2014; Vol. 3,

Issue 18, May 05; Page: 4834-4838, DOI: 10.14260/jemds/2014/2520

ABSTRACT: Malignant eccrine poroma is a malignant tumor arising from skin adnexal structure - the eccrine gland. It can be a localized tumor or sometimes it can be associated with multiple cutaneous metastases and visceral metastases.

KEYWORDS: Porocarcinoma, Basaloid -pattern, Prickle cells.

INTRODUCTION: Malignant eccrine poroma or porocarcinoma may arise denovo, however it usually develops in a long-standing eccrine poroma. ${ }^{1-6}$ The tumor favors extremities, particularly legs and feet, usually in adults of either sex. In some instances, the malignant eccrine poroma is localized, manifesting itself as a nodule, plaque, or ulcerated tumor.2,4,6,7 In other cases, there are multiple cutaneous metastases, which are usually associated with visceral metastases, resulting in death.3,5-7 The propensity to form multiple cutaneous metastases is an unusual feature of malignant eccrine poroma.

CLINICAL PRESENTATION: A 58 year old female presented with complaint of a non-healing ulcer measuring $10 \times 10 \mathrm{cms}$ on the right leg over the dorsum of foot extending from middle to base of all the toes, the duration of which was approximately one year.

MACROSCOPIC FINDINGS: A single grey black, grey brown skin covered soft tissue mass measuring $8 \times 7 \times 2.5 \mathrm{cms}$. External surface revealed an irregular polypoidal growth measuring $6.5 \times 5 \times 1 \mathrm{~cm}$. Cut section was solid grey brown grey white areas along with cystic degeneration.

HISTOPATHOLOGY: Section revealed cellular tumor where tumor cells were squamoid in nature, but smaller than the squamous cells. The nuclei were deeply basophilic in nature. These cells were distributed as nodules and anastomosing bands diffusely infiltrating the deeper subcutaneous tissue. Most of the tumor cells were similar to prickle cell layer of squamous epithelium.

Occasionally ductular differentiation was noted and there were few cysts filled with eosinophilic material. The tumor cells often exhibited varying degrees of anaplasia and pleomorphism. Few intercellular foci of melanin pigment were noted. Resected margins exhibited involvement by the tumor.

DISCUSSION: Malignant eccrine poroma may be seen associated with an eccrine poroma or a lesion of hidroacanthoma simplex.4,6 In such cases; one observes areas composed of eccrine poroma cells with a benign appearance adjacent to areas of anaplastic cells.

In the primary tumor, the malignant cells may be limited to the epidermis or may extend into the dermis. Some islands of tumor cells may lie free in the dermis. The epidermis often shows 
considerable acanthosis as a result of the proliferation of numerous well-defined tumor cell nests within it. Cystic lumina may be present within the epidermal and dermal tumor nests. The malignant cells have large, hyperchromatic, irregularly shaped nuclei and may be multinucleated. ${ }^{6}$ Lesional cells are rich in glycogen. ${ }^{1}$ The tumors are asymmetrical, with cords and lobules of polygonal tumor cells, typically with a cribriform pattern.

Nuclear atypia is evident, with frequent mitoses and necrosis. Useful clues to eccrine differentiation include spiraling ductular structures, ducts lined by cuticular material, zones of cytoplasmic glycogenation, and also intraepidermal cells in discrete aggregates, often centered on acrosyringeal pores. Foci of squamous differentiation may resemble well-differentiated squamous cell carcinoma. ${ }^{8}$

The stroma may be fibrotic, hyalinized, highly myxoid, or frankly mucinous. The distinction from metastatic adenocarcinoma, especially of breast and lung origin, can be difficult, especially for less-differentiated tumors. Ductular differentiation with formation of a PAS-positive cuticle is strong evidence against a metastasis. An extracutaneous primary adenocarcinoma should be clinically ruled out.

The term ductal eccrine carcinoma has been used to refer to tumors that may appear in the dermis as an infiltrative poroma (porocarcinoma) or as a moderately differentiated adenocarcinoma. ${ }^{9}$ About one-third of ductal eccrine carcinomas are fatal, usually because of distant metastasis. ${ }^{10}$

Malignant eccrine poroma, analogous to its benign variant, can show a clonal (intraepithelial epithelioma) pattern of its anaplastic acrosyringeal cells. The intraepidermal clones of such malignant syringoacanthomas may remain in situ or become invasive. ${ }^{11}$

In cutaneous metastases, numerous nests of tumor cells are present in both the epidermis and the dermis. In the epidermis, sharply defined small and large nests of tumor cells are seen surrounded by the squamous cells of the hyperplastic epidermis, resulting in a Pagetoid pattern.1,3 Some of the tumor nests in the dermis are located within dilated lymphatic vessels, suggesting spread of the tumor in the lymphatics of the skin. ${ }^{1}$ From the lymphatics, the tumor cells invade the overlying epidermis because of the epidermotropic nature of the tumor cells.

\section{EQUIPMENT USED:}

1. Nikon Coolpix-8400.

2. $\mathrm{x}$-denotes the power of objective.

3. Stain used - (H \& E).

\section{REFERENCES:}

1. Pinkus HM, Mehregan AH. Epidermotropic eccrine carcinoma. Arch Dermatol 1963; 88:597.

2. Mishima Y, Morioka S. Oncogenic differentiation of the intraepidermal eccrine sweat duct: eccrine poroma, poroepithelioma and porocarcinoma. Dermatologica 1969; 138: 238-250.

3. Krinitz K. Malignes itraepidermales ekkrines Porom. Zeitschrift fur Haut- und Geschlechtskrankheiten 1972;47:9-17

4. Bardach H. Hidroacanthoma simplex with in situ porocarcinoma: A case suggesting malignant transformation. J Cutan Pathol 1978; 5: 236-248.

5. Gschnait F, Horn F, Lindlbauer R, et al. Eccrine porocarcinoma. J Cutan Pathol 1980; 7: 349-353.

6. Mohri S, Chika K, Saito I, et al. A case of porocarcinoma. J Dermatology 1980; 7: 431-434. 


\section{CASE REPORT}

7. Ishikawa K. Malignant hidroacanthoma simplex. Arch Dermatol 1971; 104: 529.

8. Pena J, Suster S. Squamous differentiation in malignant eccrine poroma. Am J Dermatopathol 1993; 15: 492-496.

9. Urso CP, Paglierani M, Bondi R. Histologic spectrum of carcinomas with eccrine ductal differentiation: Sweat-gland ductal carcinomas. Am J Dermatopathol 1993;15: 435.

10. Kolde G, Macher E, Grundmann E. Metastasizing eccrine porocarcinoma. Report of two cases with fatal outcome. Pathol Res Pract 1991;187: 477-481.

11. Rahbari H. Syringoacanthoma. Acanthotic lesion of the acrosyringium. Arch Dermatol 1984;120: 751-756.

\section{MACROSCOPIC IMAGES}
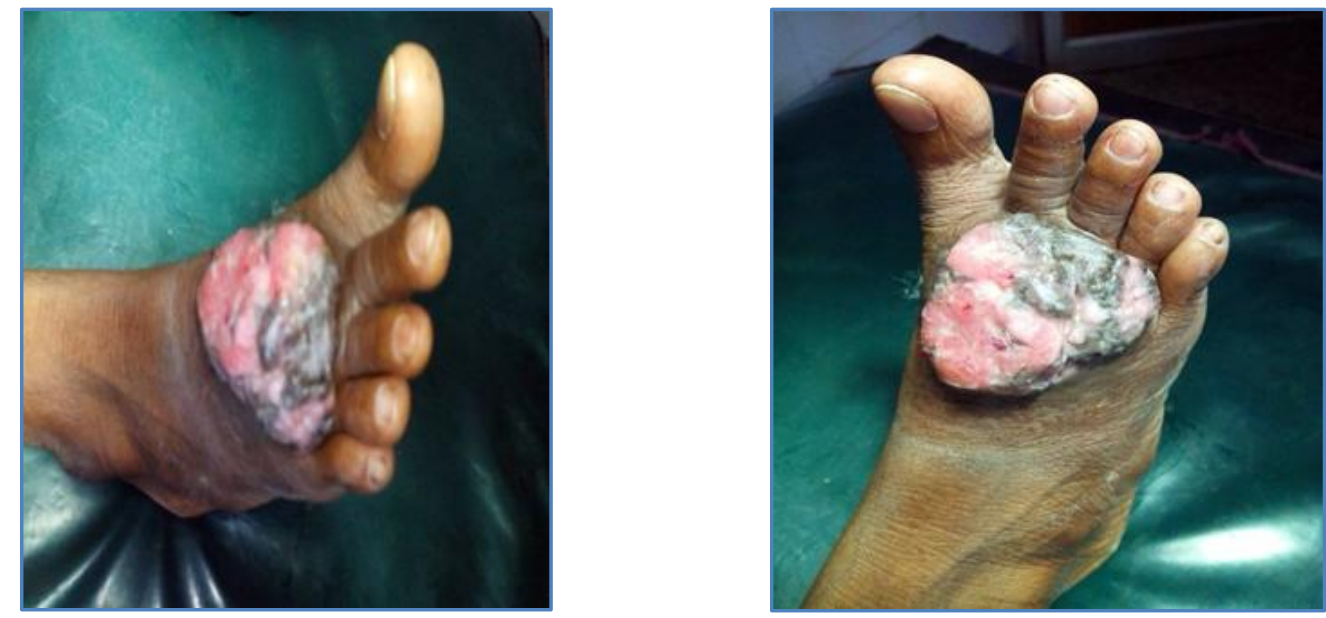

\section{MICROSCOPIC IMAGES}

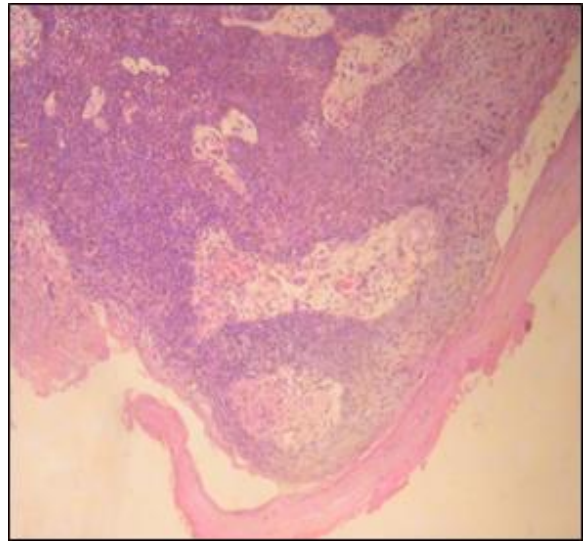

Fig. 1: H \& E stained $10 \mathrm{x}$

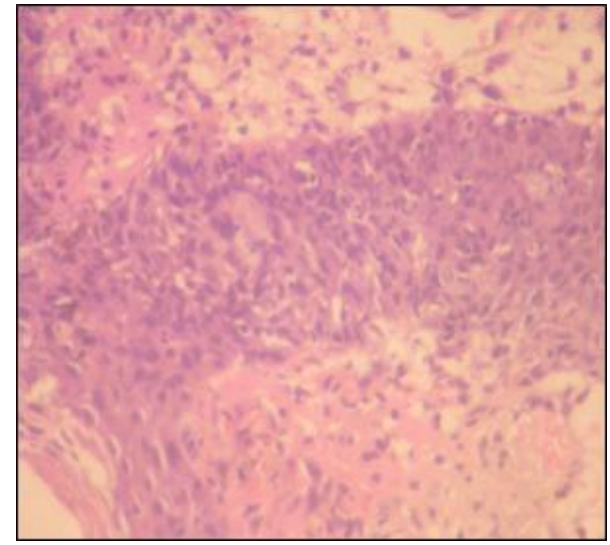

Fig. 2: H \& E stained $40 x$ 


\section{CASE REPORT}

Biopsy material where there arelarge islands of tumor cells. Also seen are anastamosing bands of tumor cells.

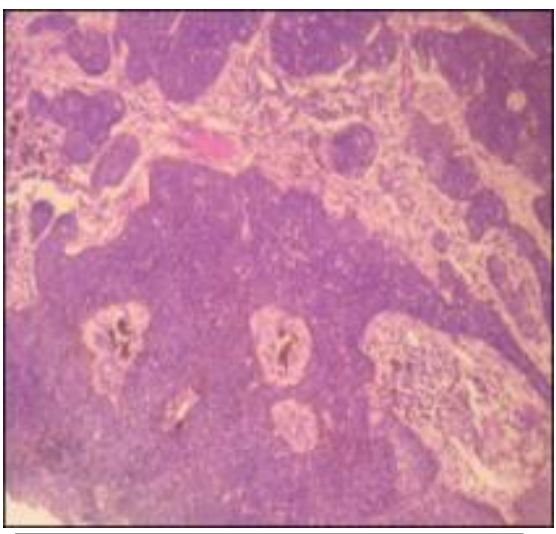

Fig. 3: H \& E stained $10 \mathrm{x}$

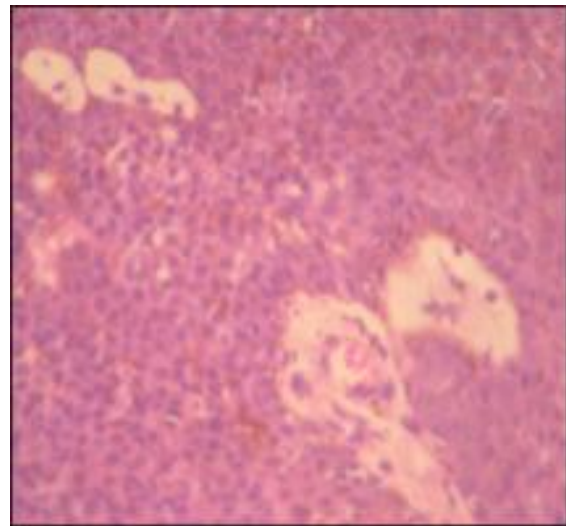

Fig. 4: H \& E stained $40 \mathrm{x}$

Foci ofmelanin pigment present among the tumour cells.

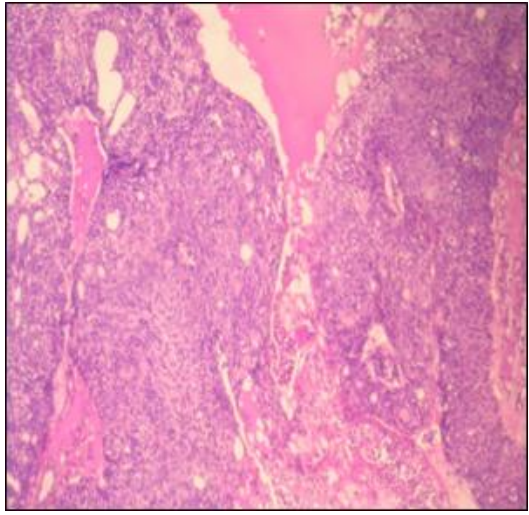

Fig. 5: H \& E stained $10 \mathrm{x}$

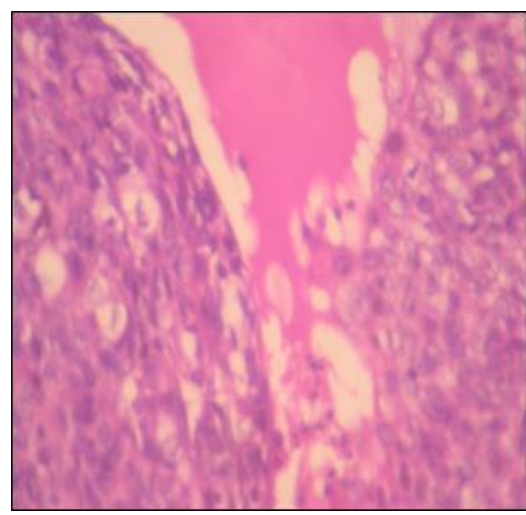

Fig 6: H \& E stained $40 \mathrm{x}$

Tumor cells tend to show vague ductular differentiation. Proteinaceous material is present between the tumor cells.

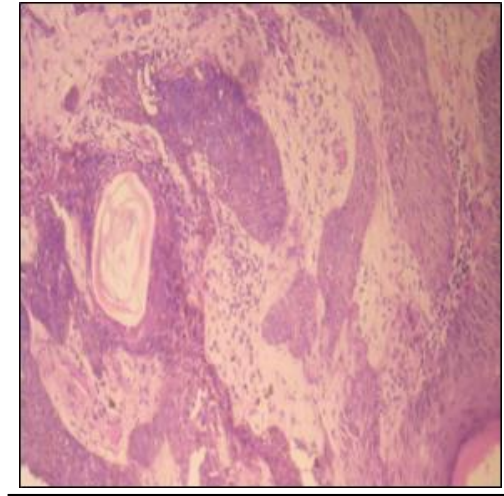

Fig. 7: H \& E stained $10 \mathrm{x}$

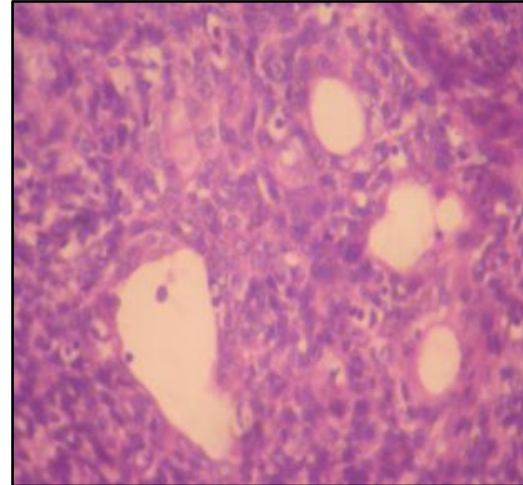

Fig. 8: H \& E stained $40 \mathrm{x}$ 
Rare keratin pearl seen among Ducts are surrounded by pleomorphic tumorcells.

\section{AUTHORS:}

1. Divvya B.

2. M. Valluvan

3. Rehana Tippoo

4. P. Viswanathan

5. R. Ramesh

\section{PARTICULARS OF CONTRIBUTORS:}

1. $1^{\text {st }}$ Year Post Graduate, Department of Pathology, Rajah Muthiah Medical College, Annamalai University.

2. $1^{\text {st }}$ Year Post Graduate, Department of Pathology, Rajah Muthiah Medical College, Annamalai University.

3. Professor, Department of Pathology, Rajah Muthiah Medical College, Annamalai University.

4. Professor, Department of Pathology, Rajah Muthiah Medical College, Annamalai University.
5. Professor, Department of Surgery, Rajah Muthiah Medical College, Annamalai University.

\section{NAME ADDRESS EMAIL ID OF THE}

\section{CORRESPONDING AUTHOR:}

Dr. P. Viswanathan,

Professor, Department of Pathology,

Faculty of Medicine,

Rajah Muthiah Medical College,

Annamalai University, Chidambaram- 608002,

Tamilnadu, India.

E-mail: drpviswanathan2013@gmail.com

Date of Submission: 13/04/2014. Date of Peer Review: 14/04/2014. Date of Acceptance: 21/04/2014.

Date of Publishing: 01/05/2014. 